UNIVERSITÀ CATTOLICA DEL SACRO CUORE

Dipartimento di Economia e Finanza

\author{
Working Paper Series
}

Financial constraints and public funding for eco-innovation: Empirical evidence on European SMEs

Grazia Cecere, Nicoletta Corrocher, Maria Luisa Mancusi

Working Paper n. 46

September 2016

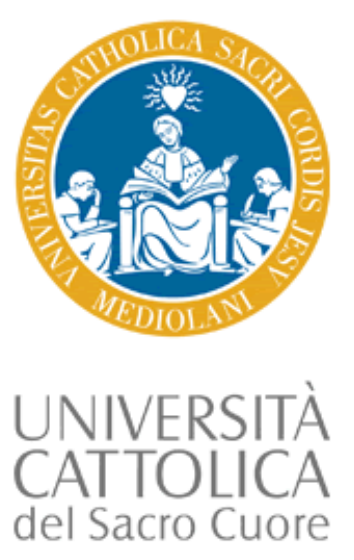




\title{
Financial constraints and public funding for eco-innovation: Empirical evidence on European SMEs
}

\author{
Grazia Cecere \\ Institut Mines-Télécom
}

\section{Nicoletta Corrocher}

Università Bocconi

\author{
Maria Luisa Mancusi \\ Università Cattolica del Sacro Cuore
}

Working Paper n. 46

September 2016

\author{
Dipartimento di Economia e Finanza \\ Università Cattolica del Sacro Cuore \\ Largo Gemelli 1 - 20123 Milano - Italy \\ tel: +39.02 .7234 .2976 - fax: +39.02 .7234 .2781$ \\ e-mail: dip.economiaefinanza@unicatt.it
}

The Working Paper Series promotes the circulation of research results produced by the members and affiliates of the Dipartimento di Economia e Finanza, with the aim of encouraging their dissemination and discussion. Results may be in a preliminary or advanced stage. The Dipartimento di Economia e Finanza is part of the Dipartimenti e Istituti di Scienze Economiche (DISCE) of the Università Cattolica del Sacro Cuore. 


\title{
Financial constraints and public funding for eco-innovation: Empirical evidence on European SMEs
}

\author{
Grazia Cecere $^{\circ}$, Nicoletta Corrocher*, Maria Luisa Mancusi^^ \\ `Institut Mines-Télécom/Télécom École de Management, 9 rue Charles Fourier, 91011 Évry, FRANCE. \\ Email: grazia.cecere@telecom-em.eu \\ *CRIOS, Bocconi University, Via Roentgen 1, 20136 Milan, ITALY. \\ Email: nicoletta.corrocher@unibocconi.it \\ ^Dipartimento di Economia e Finanza, Università Cattolica del Sacro Cuore, \\ Largo Gemelli 1, 20123 Milan, ITALY. \\ Email: marialuisa.mancusi@unicatt.it
}

\begin{abstract}
Financial constraints have an important impact on the development of eco-innovations, but their effect varies according to the type of funds taken into account. This article studies the impact of the lack of funds on the development of eco-innovations, distinguishing between internal, external and public funds. In particular, we investigate the interaction between public funding, on the one hand, and internal and other external sources of funding. The empirical analysis is based upon a sample of European SMEs belonging to different sectors that are involved in products, processes and organizational eco-innovations. Our results show that a lack of internal funding always decreases the probability to introduce ecoinnovations, while the lack of private external funds does not appear to hinder the development of eco-innovations. Interestingly, we find that access to public funds or incentives is effective in improving a firm's ability to introduce eco-innovations, but only when the firm is not short of funds (either from internal or external sources), thus suggesting that public funds are somewhat complementary to other funds. Further analysis shows that these effects are mostly relevant in small firms.
\end{abstract}

Keywords: eco-innovations, public funding, financial constraints, SMEs JEL Codes: O31, Q55, G38 


\section{Introduction}

Financing eco-innovations is essential to green growth and sustainable development, which have been set as key priorities in the policy agenda of the European Union and of other countries around the world. Within the Europe 2020 strategy, the European Eco-Innovation Action Plan aims at supporting and financing the innovative activities of firms to foster the transition towards a low carbon economy (OECD, 2009; Messeni Petruzzelli et al., 2011; European Commission, 2013). In particular, the European Union has committed to reduce the $\mathrm{CO} 2$ emissions by $80 \%$ by 2050 compared to 1990 levels. Achieving this target requires the large scale adoption of clean technologies, which are not yet competitive. While large companies have been more prone to invest in green $R \& D$ to increase their environmental efficiency and contribute to the general sustainability, SMEs have had more difficulties in devoting their limited resources to the development of green innovations (Del Brío and Junquera, 2003; Bos-Brouwers, 2010; Revell et al., 2010). In any case, private actors left on their own cannot really meet this challenge and their innovative activity needs to be coupled with government intervention that specifically addresses environmental and knowledge externalities, while stimulating and actively participating to green $R \& D$ investments, in order to bring new technologies to competitiveness (Olmos et al., 2012; Veugelers, 2012). In this context, despite the important role of demand pull policies and regulatory interventions, there is the need for the development of proper public funding schemes that complement, rather than replace, private investments (Popp, 2009; Olmos et al., 2012). Therefore, it is crucial to increase our understanding of the financial barriers to eco-innovations particularly for SMEs - and of the interplay of private and public funding for ecoinnovations, in order to provide useful insights for European policy.

The drivers of eco-innovations have been extensively discussed by the literature (Horbach, 2008; Montalvo, 2008; Horbach et al., 2012), which has recognized the importance of supplypush, demand-pull and regulatory factors in affecting the development of green innovations. However, not much emphasis has been placed on financial constraints, which instead represent a very important barrier for firms willing to carry out green research projects (Kapoor and Oksnes, 2011; Mazzanti et al., 2014; Demirel and Parris, 2015). As extensively underlined by scholars in the field of innovation studies, access to finance represents one of the most serious barriers to firms' innovative activity and growth (Mina et al., 2013; Nanda 
and Kerr, 2015; Hall et al, 2015). When firms do not have enough internal funds to allocate to innovations, they need to look for external funds, in the form of bank loans, equity capital or public financial support (e.g. subsidies, loans, tax incentives and public support to venture capital). However, returns to innovations are extremely uncertain and skewed, and information asymmetry on inputs (that are mostly intangible) and outputs make it hard to write proper "state-contingent" contracts (Nanda and Kerr, 2015). As such, financial constraints on innovations appear to be very strong and this is even more problematic for green innovations that exhibit higher risks and uncertainty than standard innovations (Aghion et al., 2009; Cuerva et al., 2014; Mazzanti et al., 2014). Therefore, in the transition towards a sustainable economy, eco innovations activities need to be, at least in part, publicly funded, due to the lack of competitiveness of clean technologies compared to the alternatives and to the uncertain effectiveness of regulations and of other public policies mechanisms. However, the effectiveness of direct public funds for the development of green innovations is questionable (Alic et al., 2003) and the design of proper funding schemes needs to take into account technological and market characteristics (Olmos et al., 2012).

This study, therefore, aims at understanding how different types of financial constraints lack of internal finance vs. lack of external (private or public) finance - affect the introduction of eco-innovations. Brown et al. (2012) suggests that it is important to consider alternative external sources of financing when studying the sensitivity of innovative investment decisions to internal finance availability. In line with this, our empirical analysis accounts for financing constraints on eco-innovations arising from both a shortage of internal liquidity and from a shortage of funding from external private and public investors. In doing so, we will explore possible interactions between public support to eco-innovation and the shortage of other funding (internal cash flow and private loans/equity capital). This will allow us to assess to what extent public and private funding are complement or substitutes.

The original contribution of the paper is threefold. First, we consider the impact of different types of financial constraints on green innovations, while the few existing contributions on the topic either look at one specific source of funding, or consider a general indicator of financial barriers. In doing so, we are able to include some reflections on the availability of public funding for SMEs, which is quite relevant in the context of eco-innovations. Second, we look at the role of financing constraints on innovation output, rather than on R\&D 
investment (i.e. innovation input). Third, we study the possible interaction between public funding and other types of funds for eco-innovations in SMEs, which typically face stronger human and financial resource constraints than large firms, but are strategic players in the path towards sustainable development.

The empirical analysis is based on data from the 2011 Eurobarometer survey on ecoinnovations, which includes information on 2082 SMEs from 27 EU countries. Our findings show that a lack of funds within the firm negatively affects the probability to introduce ecoinnovations. Moreover, the lack of public funds also appears to be an important barrier for the development of eco-innovations, but only in the absence of internal financing constraints. Indeed, when the firm declares a shortage of internal funds, public funds appear to reduce the relative probability of eco-innovating, thus suggesting a potential diversion of public funding towards alternative firm's objectives. As regards other potentially relevant factors that might affect the likelihood of eco-innovation, we find that, as expected, the probability of eco-innovation increases with size, with the share of innovation investment devoted to eco-innovation and with a positive effort in reducing material costs. We then find that firms with a strong business network and easy access to knowledge and technology are also more inclined to eco-innovate. Finally and interestingly, expectations towards the increase in material and energy prices and constraints in accessing or in the availability of materials are never found relevant in explaining the development of eco-innovations.

The article is structured as follows. Section 2 presents the theoretical framework concerning the relationship between financial constraints and the development of green innovations, focusing in particular on the existence of different types of mechanisms to raise funds and on the role of public funds. Section 3 presents the data and provides description of the sample. Section 4 illustrates the empirical model and the explanatory variables. Section 5 presents the results. Section 6 finally concludes, providing some policy implications.

\section{Eco-innovation and financial constraints: a review of the literature}

Financing eco-innovations is important to help the transition to a low carbon economy and is an important topic both for innovative companies (especially those at the early stage of business development) and for policy makers (OECD, 2012). The issue is widely discussed at 
the policy level, due to the strategic role of green innovations (European Commission, 2011). The pursue of green growth requires the involvement of different private and public actors and institutions within the economy - notably consumers, firms and policy makers - as well as the activation of substantial investments to achieve higher environmental efficiency, to develop new technologies (e.g. energy storage technologies) and green products, and to transform the society into a low carbon system. In this context, the financial system (banks and institutional investors) as well as policy makers play a very important role, as they can mobilize large amount of funds and allocate them to long-term environmental projects that often concern immature technologies or very complex technological systems (Olmos et al., 2012). However, despite the emphasis on the need to finance the path towards green growth and sustainable development, the development of a suitable system of financial support for green innovations is still in its infancy (Cainelli and Mazzanti, 2013; Mazzanti et al., 2014).

The issue of financing innovation has been extensively investigated by the literature (see Nanda and Kerr, 2015, and Hall et al., 2016 for recent reviews). Scholars have focused on the specific characteristics of R\&D projects and on the consequences of such features in terms of existing constraints to fund innovations. Most contributions studying the effects of financing constraints on innovations have focused on investment-cash flow sensitivity looking at innovation input (R\&D investment) rather than output, and have taken a measure of internal liquidity as a proxy for financing constraints. The rationale for this approach follows from the idea that the first source of financing that a firm would use when investing in innovative projects is internal liquidity. This is due to the imperfect substitutability between internal and external funds, which originates from informational asymmetries inducing a substantial difference between the cost of external finance, being it new debt or equity, and the opportunity cost of using internal finance generated through cash flow and retained earnings (Stiglitz and Weiss, 1981; Myers and Majluf, 1984).

The most relevant trait of R\&D investments compared to other types of investments is that they are highly risky and extremely uncertain, as the outcomes are unknown to potential investors (and sometimes even to the innovator itself). Uncertainty is greatest at the initial stages of the project and the information about the success or failure of the investment emerges only gradually over time (Hall, 2010; Mina et al., 2013). Furthermore, returns to innovation projects are extremely skewed (Hall and Lerner, 2010; Nanda and Kerr, 2015). 
Secondly, innovative projects are characterized by the presence of intangible assets and capital, as knowledge is embedded in human resources - researchers, technicians - working for the company and is often tacit. As employees might leave, taking with them at least part of the company's knowledge-base, companies often spread R\&D investments over a long period of time (Hall and Lerner, 2010). For all these reasons, the information asymmetries between investors and companies searching funds for their innovative projects are particularly severe, exacerbating the usual problems of opportunistic behaviors, adverse selection and moral hazard (Mina et al., 2013; Hall et al., 2016). In such contexts, evaluating the investments is extremely difficult and this has negative implications for companies both for their equity financing - because the supply of capital comes at a premium - and for their debt financing - because of the lack of collaterals associated with investments in intangible assets. It follows that internal financial constraints will typically affect the decision to invest in research. As a consequence, firms might invest in new technologies only when there is a surplus of cash, which means that they have extra liquidity available. Empirical evidence indeed shows that firms mostly use internal funds to finance innovation and this reflects a gap in the cost of capital (Hottenrott and Peters, 2012). However, internal funds are naturally limited - especially for SMEs - and therefore firms need to look for external sources of funding if they do not want to abandon their innovation projects.

Financial constraints for R\&D projects depend on firm structural characteristics, sectoral/technological contexts and geographical settings (Canepa and Stoneman, 2007; Brown et al., 2012; Cincera et al., 2016; Lööf and Nabavi, 2016). In this respect, there is evidence that green $R \& D$ projects and innovations are particularly constrained by the lack of funds (Olmos et al., 2012; Cuerva et al., 2014; Mazzanti et al., 2014), for a series of reasons that mostly relate to the existence of viable carbon-intensive alternatives. First of all, ecoinnovations are intrinsically more risky and uncertain than other investments, as they typically involve technologies that are in the initial stage of their development and therefore suffer from the existence of increasing returns (in knowledge, competencies, and infrastructure) in established, carbon-intensive technologies (Cecere et al., 2014). Second, cost-related factors are cited in the literature to be a significant strengthening factor of an existing technological trajectory in a variety of sectors. Ayres (1991) argues that the lock-in of whole technological systems was at least in part due to economies of scale. On the other side, the payback period for green R\&D investments is very long, as they usually have higher 
capital costs (Mazzanti et al., 2014). Moreover, these high costs associated with ecoinnovations tend to be irreversible, and this is problematic when prices are volatile (Cortazar et al., 1998). Third, since the financial capital market is biased towards short term profitability, the promotion of large-scale investments in new energy technologies is counterproductive for them (Walsh, 2012). Finally, the evolution and frequent changes in environmental regulations make the profitability of the innovative projects uncertain (Rennings, 2000). Most of the technological trajectories, as a result of path dependent processes in social, institutional and technological realms, are therefore often pollutionintensive (Cecere et al., 2014).

For all the reasons above specified, external finance is crucial to develop eco-innovative projects (Mazzanti et al., 2014; Demirel and Parris, 2015). As for other types of investments, firms look for private or public external finance when internal funds are not sufficient to support all their needs and activities. Private external financing instruments are bank loans, business angel capital, venture capital, corporate venturing and crowd funding (OECD, 2012). Pecking order theory (Myers and Majluf, 1984) predicts that firms would prefer debt finance, such as bank loans, to equity financing, when internal financial resources appear to be insufficient. Banks can provide different solutions, such as corporate lending, project financing or mezzanine financing. Alternatively, firms may finance innovative investment through equity financing, which has several advantages over debt for financing R\&D (see Hall, 2002). ${ }^{1}$. As for public external financing tools, it is possible to distinguish public loans/guarantees, publicly owned equity, and subsidies in the form of prized, tax credits and other benefits related to green investments, grants and contracts (Olmos et al., 2012). Subsidies can be assigned to firms that reach specific goals, regarding for example the overall percentage of sustainable products or processes developed, or to firms investing in new sustainable energy projects. The role of public interventions is particularly important in order to ensure that green $R \& D$ activities are carried out, by providing a market value to environmental benefits (Kapoor and Oksnes, 2011; Olmos et al., 2012; Cecere et al., 2014). This is because eco-innovations produce positive spillovers in both innovation and diffusion

\footnotetext{
${ }^{1}$ Among the sources of external funding, venture capital has over time acquired more and more importance. This is true also in the context of eco-innovations, with the emergence of green venture capital, whose main goal is to invest in firms that are developing new technologies that lower environmental impact, while pursuing economic goals (Randjelovic et al, 2003).
} 
stages, i.e. they can provide advantages to different economic actors than those who make the investments. These external benefits occur in the medium-long run, while the costs of green projects are concentrated upfront, and are often not even monetized or fully captured (Kapoor and Oksnes, 2011). Due to these externalities, firms have low incentives to carry out innovative projects, which typically result in under-investments (Rennings, 2000). Furthermore, the existing instruments to pull demand for green technologies - carbon pricing and deployment support measures - are insufficient to stimulate eco-innovations. However, the availability of public funding for innovation should complement rather than replace existing private funding (Olmos et al., 2012), as there are limitations in publicly managed innovative projects and, at the same time, the involvement of private actors (even in presence of public funds) appear to be crucial. Alic et al. (2003) have found evidence of both success and failure in the use of public funds to support the development of green innovations. Therefore, it is reasonable to argue that firms who can use a mixed portfolio of funds are more likely to harness the benefits from direct public support.

The importance of the financial commitment required to eco-innovate is often mentioned as a barrier to implement innovative environmental projects that is particularly important for SMEs (del Brío and Junquera 2002; Zutshi and Sohal 2004). For these firms, evidence on the effect of shortage of internal funds on innovation of any kind is mixed, probably because of the sunk cost nature of R\&D investments (Hall and Lerner, 2010) and of measurement problems (internal funds availability is typically measured through cash-flow, which is known to be problematic, as discussed in Hall and Lerner, 2010). By contrast, recent studies have found sound evidence on the detrimental effect of external financing constraints on innovation (Savignac, 2008, and Mancusi and Vezzulli, 2014) and show that it is important to account for the endogeneity of the financing constraints variable in order to uncover the negative effect of the lack of external financing. As for the impact of public funding on ecoinnovations, the available empirical evidence on the effectiveness of subsidies (and tax incentives) to promote green innovations is not conclusive (Horbach et al., 2012; Costa et al., 2014), even if some authors have indeed confirmed that public subsidies drive the development of eco-innovations (Luiten and Block, 2003; Luiten et al., 2006; Horbach, 2008; Belin et al., 2011; De Marchi, 2012). Olmos et al. (2012) argue that the effectiveness of different types of public instruments to finance green innovations (specifically in the area of clean energy) depends upon the size of the funding gap, i.e. the difference between the costs 
of the project and the available private funds, the capacity of the technology to compete for public funds with others, the likelihood of technology failure and the type of entity that carries out the investment.

\section{Data and descriptive evidence}

Our empirical analysis is based on data from the Flash Eurobarometer survey ("FL315 Attitudes of European entrepreneurs towards eco-innovation"), conducted in 2011 on behalf of the DG Environment of the European Commission, Unit F3 - Communication. The original sample includes 5222 European SMEs and it is representative of each of the $27 \mathrm{EU}$ countries.

The aim of the survey is to investigate firms' approach to eco-innovation investments. The core questions are divided into four sections. The first one focuses on material costs, asking for information about the relevance of such costs for the firm, their evolution over time (in particular, the firm's expectations on future changes in material costs), and most importantly, the changes implemented by the firm to reduce material costs. The second section directly examines the extent to which firms have engaged in different types of ecoinnovative activities. The third and fourth sections investigate the barriers to and drivers for an accelerated uptake of eco-innovations, focusing on technology/supply side factors, market/demand-side factors and regulations.

In the sample, $79 \%$ of firms are small - i.e. with 10 to 49 employees - while $21 \%$ of firms are medium size - i.e. with 50 to 249 employees. Firms mainly operate in five sectors: agriculture $(8.2 \%$ of the sample), construction $(28.3 \%)$, water supply and waste management $(3.3 \%)$, manufacturing (53.1\%), and food service activities (7\%). Table 1 reports the distribution of the firms in the sample across sectors and by size category.

The survey investigates the nature of these eco-innovations, which include product, process and organizational eco-innovations. In the overall sample, about $23.4 \%$ of the firms in the sample have developed product eco-innovation, $28.7 \%$ have introduced process ecoinnovations and $22 \%$ have implemented organization eco-innovation. There is of course overlapping between the different types of innovation, which mostly involves process innovation: $60 \%(65 \%)$ of the firms that have introduced product (organizational innovations) innovation also developed process innovations. These percentages suggest that 
it is difficult to distinguish between different types of innovation in these data and that firms might be overconfident in what they consider as innovation. Because of this, we will only focus our analysis on a unique innovation indicator, which we refine to account for innovation quality. One of the questions in the survey asks the firm to quantify the relevance of the innovation in terms of resource efficiency, measured as the reduction of material use per unit of output. 33\% of the innovating firms admit a low level of efficiency (below 5\% reduction of material use per unit of output) and another $11 \%$ is unable (or unwilling) to assess the efficiency contribution of the declared innovation. All these low quality (or low impact) innovations will therefore be ignored and the analysis will only focus on relevant innovations, that is innovations with at least a $5 \%$ reduction in material use per unit of output. The share of quality eco-innovators is thus equal to $25 \%$ of the firms in the overall sample, which is more reasonable. In what follows, when we refer to eco-innovation or innovators, we shall refer to this sub-sample of eco-innovating firms with quality innovations.

Table 1 Distribution of firms by size across sectors

\begin{tabular}{|c|c|c|c|c|}
\hline & All sample & Small firms & Medium firms & $\begin{array}{l}\text { Reduced } \\
\text { sample }\end{array}$ \\
\hline Agriculture & 8.27 & 76.39 & 23.61 & 8.76 \\
\hline Construction & 28.30 & 83.83 & 16.17 & 28.11 \\
\hline $\begin{array}{l}\text { Water supply and waste } \\
\text { management }\end{array}$ & 3.31 & 71.10 & 28.90 & 3.26 \\
\hline Manufacturing & 53.14 & 76.25 & 23.75 & 52.86 \\
\hline Food service activities & 6.97 & 88.46 & 11.54 & 7.01 \\
\hline Total & 100 & 79.09 & 20.91 & 100 \\
\hline
\end{tabular}

The second and third column in the Table respectively report the percentage of small firms (firms with 10 to 49 employees) and of medium firms (firms with 50 to 249 employees) within the sector.

As expected, this change shifts the distribution towards higher share of R\&D investment devoted to eco-innovations, but it does so only by a marginal amount, as Table 2 shows. However, it is important to note that the consideration of innovations based on their quality 
does not affect the incidence of product, process and organizational innovations, as shown in Table 3.

Table 2 Share of innovation investment devoted to eco-innovation

\begin{tabular}{lcccccc}
\hline & & & Between & & & \\
& None & Less than & $10 \%$ and & Between $30 \%$ & More than & Total \\
& & $10 \%$ & $29 \%$ & and $49 \%$ & $50 \%$ & \\
All firms & 19.37 & 36.74 & 26.59 & 9.95 & 7.36 & 100 \\
All innovators & 6.23 & 29.53 & 36.13 & 15.38 & 12.73 & 100 \\
Quality innovators & 3.17 & 22.64 & 39.83 & 19.56 & 14.81 & 100 \\
\hline
\end{tabular}

Table 3 Share of innovations by type

\begin{tabular}{lccc}
\hline & Product & Process & Organization \\
All innovators & 53.96 & 66.55 & 51.48 \\
Quality innovators & 56.02 & 71.71 & 54.83 \\
\hline
\end{tabular}

All percentages are evaluated on the number of innovating firms (i.e. firms developing at least one type of innovation). Note that percentages do not sum up to $100 \%$ because firms my pursue more than one type of innovation.

When studying innovation, it is always important to recognize that innovative firms are likely to be higher quality firms, i.e. firms with higher abilities. As an indication of this, one of the questions in the survey asked respondents if the annual turnover of the company had increased, remained unchanged or decreased over the previous two years. Table 4 shows the percentage of firms admitting a reduction in turnover, which is found to be lower in the subsample of innovators in all sectors with the exception of firms in the agriculture sector. As firm's quality is also likely to be related to the firms' ability to obtain financing from external sources, it will be an important control in our regressions.

As far as the sources of finance are concerned, the survey asks each respondent to assess the importance of three different types of financing constraints in reducing the development of eco-innovation by the firm: lack of internal funds, lack of external funds and insufficient access to existing public subsidies and fiscal incentives. The question precisely asks 
respondents to evaluate the importance of these constraints on a four point scale, from 1 (not at all important) to 4 (very important). Starting from this, we build our three key variables of interest: LACK_INT_FUND, which indicates a constraint on the development of eco-innovation originating from the lack of internal financing; LACK_EXT_FUND, which identifies constraints originating from the lack of external financing, and finally LACK_PUB_FUND, which indicates a constraint originating from the difficult in accessing public finance. Each variable is a dummy equal to one if the firm rates the corresponding lack of funds as somewhat or very important.

\section{Table 4 Share of firms with decreasing turnover}

\begin{tabular}{lcc}
\hline & All sample & Innovative firms \\
Agriculture & 34.89 & 36.30 \\
Construction & 47.19 & 43.71 \\
Water supply and waste management & 30.54 & 26.53 \\
Manufacturing & 44.43 & 38.17 \\
Food service activities & 45.45 & 38.55 \\
Total & $\mathbf{4 4 . 0 4}$ & $\mathbf{3 9 . 0 1}$ \\
\hline
\end{tabular}

Table 5 reports the percentage of firms with financing constraints by source of funds and shows that innovative firms appear to be more constrained in the development of ecoinnovation than the average firm in the sample, the percentage of constrained firms being particularly high for small innovative firms.

The evidence in Table 5, which is based on a self-assessment by the firm, should be put together with that in Table 2, which shows that distribution of the share of investment devoted to the development eco-innovation is clearly shifted to the right for innovative firms with respect to that of the average firm. Hence innovative firms invest more and perceive themselves to be more constrained than the average firm. This originates a potential identification problem in the estimation due to selection bias due to reverse causality between the perception of barriers and the innovative activity of firms (Mohnen and Röller, 
2005; Savignac, 2008; Mancusi and Vezzulli, 2014, D'Este et al., 2012). The source of selection bias is here related to the presence of firms that are not willing or interested in carrying out eco-innovation and, because of this, they do not perceive themselves as being constrained. This may generate a spurious positive correlation between the perception of financial constraints and innovative behavior (Savignac, 2008; Mancusi and Vezzulli, 2014), which may hide the negative effect of lack of funds on eco-innovation. For this reason, since we only have a cross-section of data and do not have reliable instruments to pursue instrumental variable estimation, we will run our estimates on a reduced sample of firms that excludes those firms that do not carry out any type of eco-innovation activity (including those with low resource efficiency) and that do not perceive any type of financial constraints. This excludes from the sample 597 firms: comparing the last column in Table 1 with the first one, it is clear that this reduction in the number of firms does not affect the distribution across sectors.

Table 5 Share of firms claiming lack of funds, by source of finance

\begin{tabular}{lccc}
\hline & All sample & Innovative firms & $\begin{array}{c}\text { Small innovative } \\
\text { firms }\end{array}$ \\
Lack of internal financing & 63.01 & 65.37 & 67.25 \\
Lack of external private financing & 56.84 & 62.64 & 65.18 \\
Lack of public financing & 62.04 & 69.59 & 69.94 \\
\hline
\end{tabular}

\section{Empirical model and covariates}

As already explained, our empirical analysis aims at understanding the relationship between different types of financial constraints and the development of eco-innovations. To this aim, we estimate a logit model, where our dependent variable is a dummy equal to one when the firm has developed an innovation providing at least a 5\% reduction in material use per unit of output, as explained in the previous section.

Turning to the covariates, the main variables of the model refer to financial constraints and are already described in Section 3. As previously discussed, given the specific characteristic 
of eco-innovations and the features of SMEs, we expect a shortage of internal funds and the difficulty in obtaining external financing or public funding to be negatively associated with the development of eco-innovations. The availability of different indicators of financial constraints for different sources of financing is quite unique and will allow us to study their separate effect and also an issue which has been discussed in the literature regarding the interaction of public funding with the firm's internal and external financing. For this purpose, we will introduce interactions between our LACK_PUB_FUND variable, on the one hand, and the variables LACK_INT_FUND and LACK_EXT_FUND, on the other hand. We have no clear expectation on the direction of these effects, which will depend on the type and effectiveness of public funding for eco-innovation. The literature seems to suggest that complementarity rather than substitution between public and private sources of funding should be more conducive to the development of eco-innovation, but the magnitude and significance of the interaction effects remain uncertain.

Regarding the other variables in the regression, since our model is explaining innovation output, we first need to introduce a measure of innovation input. We do not have firms' $R \& D$ investment in eco-innovations, but we know from the survey if the firm devoted a share of its innovative investments to eco-innovations and we also have a measure of that share for size categories. Specifically, as presented in Table 2, we know if the share of innovation investment related to eco-innovation is zero, positive but less than $10 \%$, between $10 \%$ and $29 \%$, between $30 \%$ and $49 \%$ and more than $50 \%$. We then obtain the variable RD, which is a categorical variable taking value from zero to 4 for different and increasing share of innovation investments devoted to eco-innovation. Of course, we cannot control for the scale of R\&D investment, which is relevant, but our variable certainly allows us to distinguish between firms doing $R \& D$ and firms not doing $R \& D$ (for whom the share is necessarily zero) and also provides information on the size of the firm's effort to ecoinnovate.

Furthermore, we can control for the reduction of material costs, which is traditionally associated with the development of both upstream and downstream eco-innovations. We know if the firm has pursued effort in reducing material costs in the five years previous to the survey year. Specifically, one question in the survey asks if the firm has implemented any of the following changes with the aim of reducing material costs: changing the business 
model; improving the material flow in the supply chain; substituting expensive materials for cheaper ones; purchasing more efficient technologies; developing more efficient technologies in-house; outsourcing production or service activities; recycling. Therefore, we will introduce the variable MATEFF, which is a dummy equal to 1 when the firm declares it has implemented at least one of the aforementioned changes in the previous five years.

We then consider the main drivers of eco-innovations, following the existing literature (Horbach, 2008; De Marchi, 2012; Horbach et al., 2012; Kesidou and Demirel, 2012; Triguero et al., 2013), which has shown the importance of technology-related factors, market variables and regulation. For this purpose, we conduct a factor analysis with varimax rotation on a set of items included in the survey's question on the drivers of eco-innovation, which the respondents are again asked to evaluate on a four point scale from not at all important $(=1)$ to very important $(=4)$. These items include: technological and management capabilities within the enterprise; secure or increased existing market share; current high material prices; limited access to materials; expected future material scarcity; collaboration with research institutes, agencies and universities; good access to external information and knowledge; good business partners; current high energy prices; expected future increases in energy prices; existing regulations, including standards; expected future regulations imposing new standards; access to existing subsidies and fiscal incentives; increasing market demand for green products. Table 6 shows the outcome of the factor analysis and the resulting factors, which we will use as covariates in our regressions to represent the main drivers of ecoinnovation.

Three factors emerge from the analysis. The first one - KNOWLEDGE \& CAPABILITIES- is explained by four main drivers: technological and management capabilities within the firm, collaboration with research institutes, agencies and universities; good access to external information and knowledge; good business partners. This factor accounts for the role of firm networks and specific competences and knowledge in driving eco-innovation and we expect it to have a positive effect on the probability to innovate (Masseni Petruzzelli et al., 2013). The second factor - REGULATION - is explained by two variables, i.e. existing regulations including standards and expected future regulations imposing new standards, and clearly indicates constraints imposed by regulation, which are an important driver for ecoinnovation. Although the evidence from the literature is not conclusive, most authors seem to agree that there is a positive relationship between regulation and the development of eco- 
innovations (Porter and van der Linde, 1995a,b; Kemp, 1997; Antonioli et al. 2013). The empirical investigation of Kesidou and Demirel (2012) shows that environmental regulation stimulates investments in the field of green innovation both in the least innovative firms and in the highly innovative firms.

Table 6 - Factor analysis: drivers of eco-innovations*

\begin{tabular}{|c|c|c|c|}
\hline & $\begin{array}{l}\text { KNOWLEDGE } \\
\text { AND } \\
\text { CAPABILITIES }\end{array}$ & REGULATION & $\begin{array}{l}\text { ENERGY AND } \\
\text { MATERIAL } \\
\text { PRICE }\end{array}$ \\
\hline $\begin{array}{l}\text { Technological and management } \\
\text { capabilities within enterprise } \\
\text { Secure or increased existing market } \\
\text { share }\end{array}$ & 0.58 & & \\
\hline Current high material prices & & & 0.56 \\
\hline Limited access to materials & & & \\
\hline Expected future material scarcity & & & \\
\hline $\begin{array}{l}\text { Collaboration with research institutes, } \\
\text { agencies and universities }\end{array}$ & 0.54 & & \\
\hline $\begin{array}{l}\text { Good access to external information } \\
\text { and knowledge }\end{array}$ & 0.62 & & \\
\hline Good business partners & 0.58 & & \\
\hline Current high energy prices & & & 0.68 \\
\hline $\begin{array}{l}\text { Expected future increases in energy } \\
\text { prices }\end{array}$ & & & 0.67 \\
\hline $\begin{array}{l}\text { Existing regulations, including } \\
\text { standards }\end{array}$ & & 0.53 & \\
\hline $\begin{array}{l}\text { Expected future regulations imposing } \\
\text { new standards }\end{array}$ & & 0.52 & \\
\hline $\begin{array}{l}\text { Access to existing subsidies and fiscal } \\
\text { incentives }\end{array}$ & & & \\
\hline $\begin{array}{l}\text { Increasing market demand for green } \\
\text { products }\end{array}$ & & & \\
\hline
\end{tabular}

The third factor - RESOURCE PRICES - is explained by the following drivers: current high energy prices, expected future increases in energy prices and current high material prices. This factor reflects the relationship between eco-innovation and energy and material prices and indicates cost reduction as one of the main triggers of eco-innovations. The first and third factor account for technology push drivers, which refer to the availability of new technologies that help firms decrease pollution or the impact of production on the environment and at the same time cut costs. Many studies have found that one of the most important reasons for firms to undertake eco-innovation is cost-savings (De Marchi, 2012; 
Horbach et al., 2012). Even though it might initially require extra capital to implement environmental friendly technologies, in the long run a firm would significantly benefit from the development of these innovations, making it more convenient to reduce the impact on the environment. Therefore, we expect the variable RESOURCE PRICES to be positively correlated with the development of eco-innovations.

We also include in our regressions a variable that accounts for firm's size - TURNOVER - i.e. a categorical variable taking value from 1 to 4 , where 1 indicates a turnover up to 2 million euros (52\% of the firms in our sample), 2 is associated with a turnover between 2 and 10 million euros (35\%), 3 indicates a turnover 10-50 million (11\%) and finally 4 indicates a turnover superior to 50 million euros (2\%). Innovation has always been found to increase with firm's size, hence we expect this variable to be relevant and to have a positive effect on the probability to eco-innovate. Finally, we include the lagged variable SUFFER, which is a dummy variable equal to 1 if there has been a reduction in the firm's turnover in the two years prior to the survey administration. As explained in the previous section, this is a way to control for firm quality and, if anything, we expect it to display a negative correlation with the probability of introducing eco-innovations.

Table 7 provides descriptive statistics for the main explanatory and control variables, while Table 8 reports sample correlations. Both are reported for the reduced sample used in the analysis, as explained above. 
Table 7 - Descriptive statistics

\begin{tabular}{|c|c|c|c|c|c|}
\hline & & Mean & Std. & Min & $\operatorname{Max}$ \\
\hline ECOINNO & $\begin{array}{l}\text { Takes value } 1 \text { if the firm introduces any eco- } \\
\text { innovation providing at least } 5 \% \text { reduction in } \\
\text { material use per unit of output, } 0 \text { otherwise }\end{array}$ & 0.28 & 0.45 & 0 & 1 \\
\hline $\mathrm{RD}$ & $\begin{array}{l}\text { Takes values } 0 \text { if the share of innovative investments } \\
\text { devoted to eco-innovation is zero, } 1 \text { if the share is } \\
\text { positive but below } 10 \%, 2 \text { if between } 10 \% \text { and } 29 \%, 3 \\
\text { if between } 30 \% \text { and } 49 \%, 4 \text { for shares equal to } 50 \% \text { or } \\
\text { above }\end{array}$ & 1.57 & 1.13 & 0 & 4 \\
\hline TURNOVER & $\begin{array}{l}\text { Annual turnover in } €: 1=\text { up to } 2 \text { million; } 2=2-10 \\
\text { million; } 3=10-50 \text { million; } 4=50 \text { million and over }\end{array}$ & 1.60 & 0.76 & 1 & 4 \\
\hline SUFFER & $\begin{array}{l}\text { Takes value } 1 \text { if the firm has experienced decreasing } \\
\text { turnover, } 0 \text { otherwise }\end{array}$ & 0.45 & 0.50 & 0 & 1 \\
\hline MATEFF & $\begin{array}{l}\text { Takes value } 1 \text { if the firm has implemented changes } \\
\text { to reduce material costs, } 0 \text { otherwise }\end{array}$ & 0.90 & 0,31 & 0 & 1 \\
\hline KNOWLEDGE \& CAPABILITIES & $\begin{array}{l}\text { Factor loading from the factor analysis on the first } \\
\text { factor }\end{array}$ & 0.09 & 0.83 & -3.23 & 1.40 \\
\hline REGULATION & $\begin{array}{l}\text { Factor loading from the factor analysis on the second } \\
\text { factor }\end{array}$ & 0.08 & 0.75 & -3.01 & 1.21 \\
\hline RESOURCE PRICE & $\begin{array}{l}\text { Factor loading from the factor analysis on the third } \\
\text { factor }\end{array}$ & 0.08 & 0.80 & -3.27 & 1.10 \\
\hline LACK_INT_FUND & $\begin{array}{l}\text { Lack of funds within enterprise from } 1 \text { (not at all } \\
\text { important) to } 4 \text { (very important) }\end{array}$ & 0.71 & 0.45 & 0 & 1 \\
\hline LACK_EXT_FUND & $\begin{array}{l}\text { Lack of external funds from } 1 \text { (not at all important) } \\
\text { to } 4 \text { (very important) }\end{array}$ & 0.64 & 0.48 & 0 & 1 \\
\hline LACK_PUB_FUND & $\begin{array}{l}\text { Insufficient access to existing subsidies and fiscal } \\
\text { incentives from } 1 \text { (not at all important) to } 4 \text { (very } \\
\text { important) }\end{array}$ & 0.70 & 0.46 & 0 & 1 \\
\hline
\end{tabular}

Table 8 Correlations

\begin{tabular}{|c|c|c|c|c|c|c|c|c|c|c|}
\hline & RD & TURNOVER & SUFFER & MATEFF & $\begin{array}{l}\text { KNOWLEDGE } \\
\text { AND CAPAB. }\end{array}$ & $\begin{array}{l}\text { RESOURCE } \\
\text { PRICES }\end{array}$ & REGUL. & $\begin{array}{l}\text { LACK } \\
\text { _INT_ } \\
\text { FUND }\end{array}$ & $\begin{array}{l}\text { LACK } \\
\text { EXXT_ } \\
\text { FUND }\end{array}$ & $\begin{array}{l}\text { LACK } \\
\text { _PUB_ } \\
\text { FUND }\end{array}$ \\
\hline RD & 1.00 & & & & & & & & & \\
\hline TURNOVER & 0.13 & 1.00 & & & & & & & & \\
\hline SUFFER & -0.07 & -0.12 & 1.00 & & & & & & & \\
\hline MATEFF & 0.18 & 0.07 & -0.00 & 1.00 & & & & & & \\
\hline $\begin{array}{l}\text { KNOWLEDGE AND } \\
\text { CAPABILITIES }\end{array}$ & 0.09 & -0.04 & 0.04 & 0.1454 & 1.00 & & & & & \\
\hline RESOURCE PRICES & 0.08 & -0.02 & 0.06 & 0.1331 & 0.73 & 1.00 & & & & \\
\hline REGULATION & 0.08 & -0.04 & 0.05 & 0.1425 & 0.84 & 0.78 & 1.00 & & & \\
\hline LACK_INT_FUND & -0.07 & -0.16 & 0.14 & 0.0118 & 0.14 & 0.14 & 0.14 & 1.00 & & \\
\hline LACK_EXT_FUND & -0.03 & -0.13 & 0.13 & 0.0419 & 0.17 & 0.16 & 0.18 & 0.34 & 1.00 & \\
\hline LACK_PUB_FUND & -0.03 & -0.08 & 0.05 & 0.0207 & 0.24 & 0.20 & 0.23 & 0.16 & 0.21 & 1.00 \\
\hline
\end{tabular}




\section{Results}

Tables 9 to 13 report the results of our estimates. All regressions include country and sector dummies, which are not reported to save space.

Table 9 Logistic regressions

(1)

(2)

(3)

(4)

Dependent variable : ECOINNO

\begin{tabular}{lcccc} 
RD & $2.061^{* * *}$ & $2.064^{* * *}$ & $2.063^{* * *}$ & $2.033^{* * *}$ \\
TURNOVER & $(0.0897)$ & $(0.0900)$ & $(0.0903)$ & $(0.0901)$ \\
& $1.276^{* * *}$ & $1.279^{* * *}$ & $1.258^{* * *}$ & $1.238^{* * *}$ \\
SUFFER & $(0.0795)$ & $(0.0799)$ & $(0.0793)$ & $(0.0786)$ \\
& & & $0.784^{* *}$ & $0.785^{* *}$ \\
MATEFF & & & $(0.0753)$ & $(0.0756)$ \\
& & & & $2.275^{* * *}$ \\
RESOURCE PRICES & & & & $(0.500)$ \\
& 1.125 & 1.117 & 1.113 & 1.116 \\
REGULATION & $(0.107)$ & $(0.106)$ & $(0.106)$ & $(0.107)$ \\
& 1.075 & 1.077 & 1.088 & 1.087 \\
KNOWLEDGE AND CAPABILITIES & $(0.140)$ & $(0.141)$ & $(0.143)$ & $(0.143)$ \\
& $1.226^{*}$ & $1.547^{* *}$ & $1.538^{* *}$ & $1.493^{* *}$ \\
LACK_INT_FUND & $(0.135)$ & $(0.283)$ & $(0.281)$ & $(0.273)$ \\
& $0.632^{* * *}$ & $0.637^{* * *}$ & $0.638^{* * *}$ & $0.634^{* * *}$ \\
LACK_FUNDS_FROM_OUTSIDE & $(0.0662)$ & $(0.0668)$ & $(0.0673)$ & $(0.0673)$ \\
& $0.741^{* *}$ & $0.708^{* *}$ & $0.712^{* *}$ & $0.717^{* *}$ \\
LACK_FUNDS_FROM_OUTSIDE*KNOWLEDGE \& CAPABILITIES & $(0.0990)$ & $(0.0957)$ & $(0.0964)$ & $(0.0969)$ \\
& & 0.762 & 0.771 & 0.779 \\
Baseline & & $(0.128)$ & $(0.129)$ & $(0.131)$ \\
& $0.197^{* * *}$ & $0.206^{* * *}$ & $0.240^{* * *}$ & $0.113^{* * *}$ \\
& $(0.0669)$ & $(0.0702)$ & $(0.0825)$ & $(0.0453)$ \\
Sector dummies & & & & \\
Country dummies & yes & yes & yes & yes \\
Observations & yes & yes & yes & yes \\
\hline
\end{tabular}

Odds-ratios. Robust sandard errors in exponentiated form reported in parentheses.

${ }^{* * *} \mathrm{p}<0.01,{ }^{* *} \mathrm{p}<0.05,{ }^{*} \mathrm{p}<0.1$

Table 9 reports estimation results from our basic specifications. Here we decided to focus on the control variables and just distinguish between lack of internal financing (LACK_INT_FUND) and lack of financing from outside the company's boundaries, whichever 
the source. We therefore use a unique indicator, LACK_FUNDS_FROM_OUTSIDE that is equal to 1 if either LACK_EXT_FUND or LACK_PUB_FUND is equal to 1.

Our initial results show that increasing the share of innovation investments devoted to ecoinnovation significantly increases the probability of eco-innovation. We investigate this effect in more details in Table 10, which reports the expected odds of eco-innovation for different values of variable RD in manufacturing, evaluated at the mean of the variables. They are suggestive of a marginal effect of RD investment which is initially increasing and then decreasing.

\section{Table 10 Odds of eco-innovation for different values of RD in manufacturing}

\begin{tabular}{lc}
\hline & Odds \\
\hline & $0.0512^{* * *}$ \\
$\mathrm{RD}=0$ & $(0.0109)$ \\
& $0.185^{* * *}$ \\
$\mathrm{RD}=1$ & $(0.0139)$ \\
& $0.412^{* * *}$ \\
$\mathrm{RD}=2$ & $(0.0206)$ \\
& $0.556^{* * *}$ \\
$\mathrm{RD}=3$ & $(0.0330)$ \\
& $0.528^{* * *}$ \\
$\mathrm{RD}=4$ & $(0.0356)$ \\
& 2,802 \\
& \\
Observations & Standard errors in parentheses \\
$* * *$ & $\mathrm{p}<0.01, * * \mathrm{p}<0.05, * \mathrm{p}<0.1$
\end{tabular}

With reference to our variables of interest on financing constraints, both the indicator of lack of internal financing and that of lack of financing from outside the firm's boundaries are significant and negatively affect the probability of eco-innovation (odds ratios are both below 1). This is an expected and interesting result that will be more in depth discussed in the rest of the section. Turning to the control variables, TURNOVER is found to be positive and significant in affecting the probability of eco-innovation. As this is a proxy for firm's size in our regression, the result is expected as larger firms may exploit economies of scale and/or economies of scope, which might increase the benefits accruing from eco-innovations. They might also have a richer resource endowment, including human capital, which can facilitate 
adoption and development of eco-innovations. Of the three variables obtained from our factor analysis on the drivers of eco-innovation, only the variable KNOWLEDGE AND CAPABILITIES is significant and positively affects the probability of eco-innovation. This variable accounts for cooperation and relationships with other organizations - universities and research institutes, as well as business partners - and for the existing competencies of firms, as well as availability of technologies. Results confirm the importance of networks where internal and external knowledge is combined to strengthen eco-innovation activities, and is coherent with previous findings (e.g. De Marchi, 2012; Messeni Petruzzelli et al., 2013). Differently from other previous studies, we do not find a significant role for regulation in the development of eco-innovations. This result might seem surprising, but it reflects the fact that regulation induced innovation incentives and other demand-pull measures cannot replace public funding support (Popp et al., 2009; Olmos et al., 2012). The finding might also be due to the fact that all firms in our sample tend to be small and instead of being proactive in the field of eco-innovations, they tend to react to external forces. As a consequence, their innovative activity is very often designed to meet regulatory requirements so that regulation is not a distinctive driver of the most innovative firms, but affects all companies.

One interesting issue that deserves further investigation is if the availability of good networks that allow the firm to access external knowledge can reduce the negative effect on eco-innovation due to the lack of financing from outside the firm, i.e. whether knowledge networks can to some extent substitute financial networks. In order to check for this possibility, in column (3)-(5) of Table 9 we introduce an interaction term between the variable KNOWLEDGE and CAPABILITIES AND LACK_FUNDS_FROM_OUTSIDE. This is never found to be significant, thus suggesting that access to external knowledge cannot reduce the negative effects of the lack of finance from outside the firm for eco-innovation. Finally, columns (3) and (4) introduce two controls for, respectively, firm quality (SUFFER) and firm effort in reducing material costs (MATEFF), which, as expected, are both found to be significant. Firms that experience a deteriorating performance on the market have a lower probability to develop eco-innovations, while firms who devoted effort to reduce material costs in the previous years and implemented changes in that direction have a higher probability to be successful in introducing eco-innovations. 
Table 11 Logistic regressions with lack of funds interactions

\begin{tabular}{|c|c|c|c|c|}
\hline Dependent variable: ECOINNO & (1) & (2) & (3) & $(4)$ \\
\hline RD & $\begin{array}{l}2.042^{* * *} \\
(0.0917)\end{array}$ & $\begin{array}{l}2.038^{* * *} \\
(0.0916)\end{array}$ & $\begin{array}{l}2.036 * * * \\
(0.0915)\end{array}$ & $\begin{array}{l}2.034^{* * *} \\
(0.0915)\end{array}$ \\
\hline TURNOVER & $\begin{array}{l}1.233^{* * *} \\
(0.0791)\end{array}$ & $\begin{array}{l}1.231^{* * *} \\
(0.0790)\end{array}$ & $\begin{array}{l}1.232^{* * *} \\
(0.0790)\end{array}$ & $\begin{array}{l}1.231^{* * *} \\
(0.0790)\end{array}$ \\
\hline SUFFER & $\begin{array}{l}0.776^{* * *} \\
(0.0753)\end{array}$ & $\begin{array}{l}0.776^{* * *} \\
(0.0754)\end{array}$ & $\begin{array}{l}0.773^{* * *} \\
(0.0752)\end{array}$ & $\begin{array}{l}0.774^{* * *} \\
(0.0753)\end{array}$ \\
\hline MATEFF & $\begin{array}{c}2.393 * * * \\
(0.533)\end{array}$ & $\begin{array}{c}2.387^{* * *} \\
(0.534)\end{array}$ & $\begin{array}{c}2.381^{* * *} \\
(0.534)\end{array}$ & $\begin{array}{c}2.378^{* * *} \\
(0.534)\end{array}$ \\
\hline KNOWLEDGE AND CAPABILITIES & $\begin{array}{l}1.217^{*} \\
(0.136)\end{array}$ & $\begin{array}{l}1.212^{*} \\
(0.135)\end{array}$ & $\begin{array}{l}1.213^{*} \\
(0.136)\end{array}$ & $\begin{array}{l}1.211^{*} \\
(0.136)\end{array}$ \\
\hline RESOURCE PRICES & $\begin{array}{c}1.119 \\
(0.108)\end{array}$ & $\begin{array}{c}1.124 \\
(0.109)\end{array}$ & $\begin{array}{c}1.128 \\
(0.110)\end{array}$ & $\begin{array}{c}1.130 \\
(0.110)\end{array}$ \\
\hline REGULATION & $\begin{array}{c}1.086 \\
(0.144)\end{array}$ & $\begin{array}{c}1.084 \\
(0.144)\end{array}$ & $\begin{array}{c}1.075 \\
(0.143)\end{array}$ & $\begin{array}{c}1.075 \\
(0.143)\end{array}$ \\
\hline LACK_INT_FUND & $\begin{array}{l}0.636^{* * *} \\
(0.0699)\end{array}$ & $\begin{array}{l}0.634^{* * *} \\
(0.0698)\end{array}$ & $\begin{array}{l}0.483^{* * *} \\
(0.0892)\end{array}$ & $\begin{array}{l}0.497^{* * *} \\
(0.0923)\end{array}$ \\
\hline LACK_EXT_FUND & $\begin{array}{c}0.883 \\
(0.0956)\end{array}$ & $\begin{array}{c}0.746 \\
(0.134)\end{array}$ & $\begin{array}{c}0.877 \\
(0.0954)\end{array}$ & $\begin{array}{c}0.799 \\
(0.146)\end{array}$ \\
\hline LACK_PUB_FUND & $\begin{array}{c}0.874 \\
(0.0958)\end{array}$ & $\begin{array}{l}0.761^{*} \\
(0.123)\end{array}$ & $\begin{array}{l}0.675^{* *} \\
(0.123)\end{array}$ & $\begin{array}{l}0.643^{* *} \\
(0.129)\end{array}$ \\
\hline LACK_EXT_FUND*LACK_PUB_FUND & & $\begin{array}{c}1.281 \\
(0.278)\end{array}$ & & $\begin{array}{c}1.145 \\
(0.256)\end{array}$ \\
\hline LACK_INT_FUND*LACK_PUB_FUND & & & $\begin{array}{c}1.506 * \\
(0.336)\end{array}$ & $\begin{array}{c}1.441 \\
(0.330)\end{array}$ \\
\hline Baseline & $\begin{array}{c}0.0921^{* * *} \\
(0.0366)\end{array}$ & $\begin{array}{l}0.101^{* * *} \\
(0.0409)\end{array}$ & $\begin{array}{l}0.108^{* * *} \\
(0.0439)\end{array}$ & $\begin{array}{l}0.111^{* * *} \\
(0.0459)\end{array}$ \\
\hline Sector dummies & yes & yes & yes & yes \\
\hline Country dummies & yes & yes & yes & yes \\
\hline Observations & 2,736 & 2,736 & 2,736 & 2,736 \\
\hline
\end{tabular}

Odds-ratios. Robust sandard errors in exponentiated form reported in parentheses.

${ }^{* * *} \mathrm{p}<0.01,{ }^{* *} \mathrm{p}<0.05,{ }^{*} \mathrm{p}<0.1$

As already explained, the focus of our empirical analysis is to investigate the impact of financial constraints on the development of eco-innovations, distinguishing between the lack of funds within the enterprise and the lack of private and public external financing. In particular, we aim at exploring the interactions between different types of funding, in order to understand the extent to which public funds are effective complements/substitutes to 
private funds to stimulate green innovations. We therefore turn to this in Table 11, which includes all our three variables of financing constraints and our control variables. Columns (2)-(4) also include the interactions between the lack of public funds, on the one hand, and the lack of internal and external financing, on the other. Results on the control variables are all confirmed and the lack of internal funds is always found to have a negative impact on the probability of carrying out eco-innovations, thus confirming that the availability of internal funds is a key determinant of firms' innovative activity. Eco-innovation investments are particularly uncertain, making internal liquidity an important requirement for firms willing to develop these types of innovative projects. By contrast, the lack of external funds is never found to be significant, which is somewhat surprising. However, the lack of public funding appears to have a significant effect on the probability of developing eco-innovations, which confirms the important role of the public direct intervention to support the transition towards a low-carbon economy. An even more interesting result comes from the analysis of the interaction effects between public funding and other sources of funding. Indeed, the lack of public funding appears to significantly interact with the lack of internal funds in its effect on the probability to innovate. To better interpret these interaction effects, we report in Table 12 the odds of eco-innovation for every combination of the variables involved in the interactions.

First of all, note that the odds for each specific combination are very similar if we consider the specification that includes just that interaction (column (2) and column (3) in Table 11) or the specification with both interactions included (column (4) in Table 11). So we will focus our comments on the first two columns in Table 12, but they also apply to the third column in the same table.

Looking at the first column of Table 12 and focusing on the first two rows, we can think of the marginal effect of the lack of public funding when the firm has no lack of external financing as the difference between the expected odds of firms with and without lack of public funding when LACK_EXT_FIN is equal to zero (Buis, 2010). That difference is equal to 0.36 and is statistically significant at the $5 \%$ level. Hence, releasing the financing constraint originating from access to public funds for firms without lack of external financing is effective in increasing the odds in favor of eco-innovation. By contrast, public funding appears ineffective for firms with external financing constraints, which suggests some kind of complementarity between external financing and public funding. 
Table 12 Odds ratios for lack of funds interactions

\begin{tabular}{lccc}
\hline & $\begin{array}{c}\text { Odds from } \\
\text { specification } \\
(2) \text { in Table 11 }\end{array}$ & $\begin{array}{c}\text { Odds from } \\
\text { specification } \\
(3) \text { in Table 11 }\end{array}$ & $\begin{array}{c}\text { Odds from } \\
\text { specification } \\
(4) \text { in Table 11 }\end{array}$ \\
\hline & & & $1.111^{* * *}$ \\
LACK_EXT_FUND=0, LACK_PUB_FUND=0 & $\begin{array}{c}1.066^{* * *} \\
(0.144)\end{array}$ & & $(0.159)$ \\
LACK_EXT_FUND=0, LACK_PUB_FUND=1 & $0.707^{* * *}$ & & $0.699^{* * *}$ \\
& $(0.0800)$ & & $(0.0787)$ \\
LACK_EXT_FUND=1, LACK_PUB_FUND=0 & $0.602^{* * *}$ & & $0.624^{* * *}$ \\
& $(0.0841)$ & & $(0.0904)$ \\
LACK_EXT_FUND=1, LACK_PUB_FUND=1 & $0.629^{* * *}$ & & $0.626^{* * *}$ \\
& $(0.0467)$ & & $(0.0464)$ \\
LACK_INT_FUND=0, LACK_PUB_FUND=0 & & $1.485^{* * *}$ & $1.490^{* * *}$ \\
& & $(0.230)$ & $(0.231)$ \\
LACK_INT_FUND=0, LACK_PUB_FUND=1 & & $0.807^{* * *}$ & $0.806^{* * *}$ \\
LACK_INT_FUND=1, LACK_PUB_FUND=0 & & $(0.0952)$ & $(0.0949)$ \\
& & $0.475^{* * *}$ & $0.476^{* * *}$ \\
LACK_INT_FUND=1, LACK_PUB_FUND=1 & & $(0.0572)$ & $(0.0573)$ \\
& & $0.600^{* * *}$ & $0.599^{* * *}$ \\
& & $(0.0439)$ & $(0.0439)$ \\
& & & \\
\hline
\end{tabular}

Standard errors in parentheses. ${ }^{* *} \mathrm{p}<0.01,{ }^{* *} \mathrm{p}<0.05,{ }^{*} \mathrm{p}<0.1$

Looking now at the second column in Table 12, we can obtain the marginal effect of the lack of public funding when the firm has no lack of internal financing as the difference between the expected odds of firms with and without lack of public funding when LACK_INT_FIN is equal to zero. That difference is equal to -0.68 and is statistically significant at the $1 \%$ level. Hence, releasing the financing constraint originating from access to public funds for firms without lack of internal financing is effective in increasing the odds in favor of ecoinnovation. By contrast, public funding appears to have the opposite effect when the firm suffers from internal financing constraints, i.e. when LACK_INT_FIN is equal to one. In this case, the difference in the odds is much smaller, but positive (0.12) and significant at the $10 \%$ level, but close to $5 \%$. This result suggests that access to sufficient public funds for firms suffering from internal financing constraints has, if anything, a negative effect on the probability of eco-innovation, possibly because public funds are diverted towards other needs of the firm. 
Table 13 Logistic regressions with lack of funds interactions by firm size

\begin{tabular}{|c|c|c|c|c|c|c|}
\hline Dependent variable: ECOINNO & $\begin{array}{c}(1) \\
\text { small }\end{array}$ & $\begin{array}{c}(2) \\
\text { small }\end{array}$ & $\begin{array}{c}(3) \\
\text { small }\end{array}$ & $\begin{array}{c}(4) \\
\text { medium }\end{array}$ & $\begin{array}{c}(5) \\
\text { medium }\end{array}$ & $\begin{array}{c}(6) \\
\text { medium }\end{array}$ \\
\hline RD & $\begin{array}{c}2.032^{* * *} \\
(0.106)\end{array}$ & $\begin{array}{c}2.036^{* * *} \\
(0.106)\end{array}$ & $\begin{array}{c}2.037^{* * *} \\
(0.106)\end{array}$ & $\begin{array}{c}2.186^{* * *} \\
(0.222)\end{array}$ & $\begin{array}{c}2.187^{* * *} \\
(0.222)\end{array}$ & $\begin{array}{c}2.187^{* * *} \\
(0.222)\end{array}$ \\
\hline TURNOVER & $\begin{array}{c}1.313^{* * *} \\
(0.115)\end{array}$ & $\begin{array}{c}1.315^{* * *} \\
(0.115)\end{array}$ & $\begin{array}{c}1.311^{* * *} \\
(0.116)\end{array}$ & $\begin{array}{c}1.097 \\
(0.152)\end{array}$ & $\begin{array}{c}1.097 \\
(0.152)\end{array}$ & $\begin{array}{c}1.098 \\
(0.153)\end{array}$ \\
\hline SUFFER & $\begin{array}{c}0.765^{* *} \\
(0.0861)\end{array}$ & $\begin{array}{c}0.764^{* *} \\
(0.0859)\end{array}$ & $\begin{array}{c}0.767^{* *} \\
(0.0862)\end{array}$ & $\begin{array}{c}0.760 \\
(0.160)\end{array}$ & $\begin{array}{c}0.760 \\
(0.160)\end{array}$ & $\begin{array}{c}0.760 \\
(0.160)\end{array}$ \\
\hline MATEFF & $\begin{array}{c}2.942 * * * \\
(0.791)\end{array}$ & $\begin{array}{c}2.930 * * * \\
(0.785)\end{array}$ & $\begin{array}{c}2.981^{* * *} \\
(0.795)\end{array}$ & $\begin{array}{c}0.969 \\
(0.438)\end{array}$ & $\begin{array}{c}0.962 \\
(0.429)\end{array}$ & $\begin{array}{c}0.963 \\
(0.435)\end{array}$ \\
\hline KNOWLEDGE AND CAPABILITIES & $\begin{array}{c}1.231 \\
(0.162)\end{array}$ & $\begin{array}{c}1.235 \\
(0.163)\end{array}$ & $\begin{array}{c}1.230 \\
(0.161)\end{array}$ & $\begin{array}{c}1.178 \\
(0.271)\end{array}$ & $\begin{array}{c}1.177 \\
(0.270)\end{array}$ & $\begin{array}{c}1.180 \\
(0.271)\end{array}$ \\
\hline RESOURCE PRICES & $\begin{array}{c}1.108 \\
(0.126)\end{array}$ & $\begin{array}{c}1.105 \\
(0.126)\end{array}$ & $\begin{array}{c}1.098 \\
(0.124)\end{array}$ & $\begin{array}{c}1.149 \\
(0.240)\end{array}$ & $\begin{array}{c}1.151 \\
(0.240)\end{array}$ & $\begin{array}{c}1.148 \\
(0.240)\end{array}$ \\
\hline REGULATION & $\begin{array}{c}1.089 \\
(0.168)\end{array}$ & $\begin{array}{c}1.090 \\
(0.169)\end{array}$ & $\begin{array}{c}1.104 \\
(0.170)\end{array}$ & $\begin{array}{c}1.077 \\
(0.300)\end{array}$ & $\begin{array}{c}1.077 \\
(0.299)\end{array}$ & $\begin{array}{c}1.077 \\
(0.300)\end{array}$ \\
\hline LACK_INT_FUND & $\begin{array}{l}0.449 * * * \\
(0.0954)\end{array}$ & $\begin{array}{l}0.424^{* * *} \\
(0.0903)\end{array}$ & $\begin{array}{l}0.611^{* * *} \\
(0.0785)\end{array}$ & $\begin{array}{c}0.653 \\
(0.254)\end{array}$ & $\begin{array}{c}0.666 \\
(0.252)\end{array}$ & $\begin{array}{c}0.691 \\
(0.157)\end{array}$ \\
\hline LACK_PUB_FUND & $\begin{array}{c}0.514^{* * *} \\
(0.123)\end{array}$ & $\begin{array}{c}0.576^{* * *} \\
(0.123)\end{array}$ & $\begin{array}{l}0.641^{* *} \\
(0.123)\end{array}$ & $\begin{array}{c}0.962 \\
(0.372)\end{array}$ & $\begin{array}{c}0.939 \\
(0.339)\end{array}$ & $\begin{array}{c}0.996 \\
(0.321)\end{array}$ \\
\hline LACK_EXT_FUND & $\begin{array}{c}0.727 \\
(0.151)\end{array}$ & $\begin{array}{c}0.891 \\
(0.111)\end{array}$ & $\begin{array}{l}0.669^{*} \\
(0.138)\end{array}$ & $\begin{array}{c}0.895 \\
(0.363)\end{array}$ & $\begin{array}{c}0.844 \\
(0.202)\end{array}$ & $\begin{array}{c}0.878 \\
(0.348)\end{array}$ \\
\hline LACK_INT_FUND\#.LACK_PUB_FUND & $\begin{array}{l}1.588^{*} \\
(0.421)\end{array}$ & $\begin{array}{l}1.739 * * \\
(0.454)\end{array}$ & & $\begin{array}{c}1.089 \\
(0.520)\end{array}$ & $\begin{array}{c}1.056 \\
(0.474)\end{array}$ & \\
\hline LACK_EXT_FUND\#.LACK_PUB_FUND & $\begin{array}{c}1.347 \\
(0.349)\end{array}$ & & $\begin{array}{c}1.541^{*} \\
(0.391)\end{array}$ & $\begin{array}{c}0.920 \\
(0.442)\end{array}$ & & $\begin{array}{c}0.948 \\
(0.428)\end{array}$ \\
\hline Baseline & $\begin{array}{l}0.118^{* * *} \\
(0.0569)\end{array}$ & $\begin{array}{l}0.109 * * * \\
(0.0523)\end{array}$ & $\begin{array}{l}0.102^{* * *} \\
(0.0486)\end{array}$ & $\begin{array}{l}0.125^{* *} \\
(0.118)\end{array}$ & $\begin{array}{l}0.128^{* *} \\
(0.117)\end{array}$ & $\begin{array}{l}0.124^{* *} \\
(0.116)\end{array}$ \\
\hline Sector dummies & yes & yes & yes & yes & yes & yes \\
\hline Country dummies & yes & yes & yes & yes & yes & yes \\
\hline Observations & 2,135 & 2,135 & 2,135 & 596 & 596 & 596 \\
\hline
\end{tabular}

An important robustness exercise that we perform is to split the sample depending on firm size between small firms (below 50 employees) and medium firms (between 50 and 249 employees). Results are reported in Table 13 and show that all the effects we discussed are confined to small firms, thus confirming that this is the group of firms that mostly suffer 
from financing constraints and for which public policy may be effective in increasing their innovation performance.

\section{Conclusions}

The aim of this paper has been to shed light on the importance of financial constraints on the development of eco-innovations by SMEs, whose innovative activities are perceived as being increasingly crucial for green growth. Indeed, both research and policy actions have emphasized that SMEs are more flexible than large firms and can benefit from the opportunities associated with the emerging paradigm (OECD, 2011). However, the process of green entrepreneurship by small firms faces important obstacles, among which financing and, more in general, resource constraints represent relevant challenges. Specifically, the analysis has investigated the extent to which internal and external private and public funds are conducive to the development of eco-innovations. Furthermore, given the specificities of eco-innovations, we have put particular emphasis on the interplay between public funding and other sources of funding, and its effectiveness.

The results show that a lack of internal funds within the firm negatively affects the probability to introduce eco-innovations, as well as the lack of public funds. These findings are particularly strong for small firms (as opposed to medium-size firms), thus confirming that these are the firms that mostly suffer from financing constraints and for which public policy may be effective in stimulating their innovation activity. The analysis of the interaction between public funds and other sources of funds shows that, while the availability of public funds has a positive impact on eco-innovations when firms have internal financial resources, it has negative effects on eco-innovations when firms suffer from internal financing constraints. This important result suggests that public support to green innovation is complementary to the availability of private funds and that, in absence of internal funding, public funds are diverted towards other needs of the firm.

As for other variables, it is interesting to notice that cooperation with universities and firms positively affect the probability to introduce eco-innovation which corroborates previous empirical findings (De Marchi, 2012; Horbarch et al. 2012). On the contrary, once the availability of public and private funds is taking into consideration, the role of regulation is 
limited, suggesting that, at least for SMEs, public funding support for the development of green innovations cannot be replaced by regulatory support (Olmos et al., 2012).

Our results have important policy implications. In particular, they show that, in order to design suitable innovation policy mechanisms and to organize the provision of direct support for the development of eco-innovations, internal financial constraints of firms should be taken into account. On the one hand, the availability of public funding is an important facilitator of eco-innovations, particularly for small companies that suffer from a lack of equity financing and a shortage of loans and whose access to funding is not usually facilitated by banks and private institutions. In this sense, access to regional and national funding could be simplified in order to reduce the administrative burdens and allow the participation of SMEs. Furthermore, policy makers could facilitate the procedures to obtain environmental certifications, which often drive organizational innovations in SMEs. On the other hand, if this support is provided in the absence of private internal funds, the risk of public funds being diverted to other firms' needs is high. Therefore, the direct public support of eco-innovation activities should complement private R\&D investments instead of simply being a source of liquidity for financially constrained firms.

Another important result in terms of policy implications is the importance of firms' networking with business actors and with research centers and universities. This suggests that it is important to encourage cooperation between universities and firms, in order to combine different knowledge bases and technological competences for the development of eco-innovations. The relevance of knowledge networks however does not attenuate the negative effect of the financial constraints, suggesting that policies aiming at stimulating the development of research networks in the area of sustainable development need to go hand in hand with the provision of direct financial support to private innovative activity.

Finally, once financial constraints are taken into consideration in the analysis, regulation does not have a major role in the development of eco-innovations. Policy makers should therefore design policy mechanisms to support eco-innovations activity that include not only demand pull measures (e.g. carbon pricing) for more mature technologies and regulation induced innovation incentives such as the definition of standards, but also direct financial support to companies that show long-term and sustainable commitment to eco-innovations. 


\section{References}

Aghion, P., Veugelers, R. ,Hemous, D. 2009. No green growth without innovation. Bruegel Policy Briefs, 7, 1-8.

Alic, J.A., Mowery, D.C., Rubin, E.S. 2003. US technology and innovation policies: lessons for climate change. Pew Center for Global Climate Change, Arlington, VA. Available at: http:/ / repository.cmu.edu/cgi/viewcontent.cgi?article=1095\&context=epp.

Antonioli, D., Mancinelli, S. Mazzanti, M. 2013. Is environmental innovation embedded within high-performance organizational changes? The role of human resource management and complementarity in green business strategies, Research policy 42,975-988.

Ayres, R. 1991. Evolutionary economics and environmental imperatives. Structural Change and Economic Dynamics 2(2), 255-273.

Belin, J., J. Horbach, Oltra. V. 2011. Determinants and specificities of eco-innovations - an econometric analysis for France and Germany based on Community Innovation Survey. Cahiers du GREThA n 2011-17.

Bos-Brouwers, H.E.J. 2010. Corporate sustainability and innovation in SMEs: evidence of themes and activities in practice. Business Strategy and the Environment 19(7), 417-435.

Brown J.R., Martinsson G., Petersen B.C. 2012. Do Financing Constraints Matter for R\&D?. European Economic Review 56(8), 1512-1529.

Buis M.L. 2010. Interpretation of interactions in nonlinear models. The Stata Journal 10(2), 305-308.

Cainelli, G., Mazzanti, M. 2013. Environmental innovations in services: Manufacturingservices integration and policy Transmission. Research Policy42(9), 1595-1604.

Canepa, A., Stoneman, P. 2007. Financial constraints to innovation in the UK: evidence from CIS2 and CIS 3. Oxford Economic Papers 60, 711-730.

Cecere, G., Corrocher, N., Gossart, C., Ozman, M. 2014. Eco-innovations and the evolutionary approach to technical change: a review of the literature. Journal of Evolutionary Economics 24 (5), pp. 1037-1065

Cincera, M., Ravet, J., Veugelers, R. 2016. The sensitivity of R\&D investments to cash flows: comparing young and old EU and US leading innovators. Economics of Innovation and New Technology 25(3), 304-320.

Cortazar, G., Schwartz, E.S., Salinas, M. 1998. Evaluating environmental investments: a real options approach. Management Science 44(8), 1059-1070.

Costa, M.T., Garcia-Quevedo, J. ,Segarra, A. (2014). Energy efficiency determinants: An empirical analysis of Spanish innovative firms. IEB Working Paper N. 2014/10. 
Cuerva, M.C., Triguero-Cano, Á., Córcoles, D. 2014. Drivers of green and non-green innovation: empirical evidence in low-tech SMEs. Journal of Cleaner Production 68, 104-113.

De Marchi, V. 2012. Environmental innovation and R\&D cooperation: Empirical evidence from Spanish manufacturing firms. Research Policy 41(3), 614-623.

Del Brío, J.Á., Junquera, B. 2003. A review of the literature on environmental innovation management in SMEs: implications for public policies. Technovation 23(12), 939-948.

Demirel, P., Parris. S, 2015. Access to finance for innovators in the UK's environmental sector. Technology Analysis and Strategic Management 27(7), 782-808.

D'Este,P., Iammarino, S., Savona, M.,von Tunzelmann, N. 2012. What hampers innovation? Revealed barriers versus deterring barriers. Research Policy 41, 482 - 488.

European Commission, 2011. Financing eco-innovation. Final Report, EIM and Oxford Research for the European Commission, DG Environment.

European Commission, 2013. Europe in Transition. Paving the way to a green economy through eco-innovation. Eco-innovation observatory, Annual Report 2012.

Hall B.H., 2002. The financing of research and development. Oxford Review of Economic Policy, 18 (1), 35-51.

Hall B.H., Lerner J., 2010. The Financing of R\&D and Innovation. In: Hall B.H. and Rosenberg N. (Eds.), Handbook of the Economics of Innovation. Elsevier-North Holland.

Hall, B.H., Moncada-Paternò Castello, P., Montresor, S., Vezzani, A. 2016. Financing constraints, R\&D investments and innovative performances: new empirical evidence at the firm level for Europe. Economics of Innovation and New Technology 25(3), 183-196.

Horbach, J. 2008. Determinants of Environmental Innovation - New Evidence from German Panel Data Sources. Research Policy 37, 163-173.

Horbach, J., Rammer, C. , Rennings, K. 2012. Determinants of Eco-innovations by Type of Environmental Impact - The Role of Regulatory Push/Pull, Technology Push and Market Pull. Ecological Economics, 78, 112-122.

Hottenrott, H., Peters, B. 2012. Innovative capability and financinig constraints for innovation: More money, more innovation? Review of Economics and Statistics, 94(4), 11261142.

Kapoor, S., Oksnes, L. 2011. Funding the Green New Deal: Building a Green Financial System. Green European Foundation. Green New Deal Series Vol. 6.

Kemp, R. 1997. Environmental Policy and Technical Change. Edward Elgar, Cheltenham, Brookfield. 
Kesidou, E , Demirel, P. 2012. On the drivers of eco-innovations: Empirical evidence from the UK. Research Policy, 41(5), 862-870.

Lööf, H., Nabavi, P. 2016. Innovation and credit constraints: evidence from Swedish exporting firms. Economics of Innovation and New Technology, 25(3), 269-282.

Luiten, E.E., Block, K. 2003. Stimulating R\&D of industrial energy-efficient technology; the effect of government intervention on the development of strip casting technology. Energy Policy, 31(13), 1339-1356.

Luiten, E., van Lente, H., Block, K. 2006. Slow technologies and government intervention: Energy efficiency in industrial process technologies. Technovation, 26(9), 1029-1044.

Mancusi, M.L.,Vezzulli, A. 2014 R\&D and Credit Rationing in SMEs. Economic Inquiry, 52(3) 1153-1172.

Mazzanti, M., Antonioli, D., Mancinelli, S., Ghisetti, C. 2014. The availability of finance for the low carbon economy. Evidence on eco innovation diffusion from sector analysis. WP4 Deliverable 4.4. Ferrara, University of Ferrara. Available at: http://cecilia2050.eu/publications/259.

Messeni Petruzzelli, A., Dangelico, R.M., Rotolo, D., Albino, V. 2011. Organizational factors and technological features in the development of green innovations: Evidence from patent analysis. Innovation: Management, Policy \& Practice 13, 291-310.

Mina, A., Lahr, H., Hughes, A. 2013. The demand and supply of external finance for innovative firms. Industrial and Corporate Change, 22(4), 1-33.

Mohnen, P., Roller, L.-H. 2005. Complementarities in innovation policy. European Economic Review, 49(6), 1431-1450

Montalvo, C. 2008. General wisdom concerning the factors affecting the adoption of cleaner technologies: a survey 1990-2007. Journal of Cleaner Production 16, S7-S13.

Myers S.C., Majluf, N. 1984. Corporate Financing and Investment Decisions When Firms Have Information That Investors Do Not Have. Journal of Financial Economics, 13(2), 187221.

Nanda R., Kerr W.R. 2015. Financing Innovation. Annual Review of Financial Economics, $7(1), 445-462$.

OECD 2009. Measuring the Relationship between ICT and the Environment. OECD Publishing, Paris.

OECD, 2011. SMEs and Entrepreneurship: Green Growth, Innovation and Employment. Centre for Entrepreneurship, SMEs and Local Development, OECD, Paris.

OECD, 2012. OECD Science, Technology and Industry Outlook. OECD, Paris. 
Olmos, L., Ruester, S., Liong, S-J. 2012. On the selection of financing instruments to push the development of new technologies: Application to clean energy technologies. Energy Policy $43,252-266$.

Popp, D., Newell, R.G., Jaffe, A.B. 2009. Engergy, the environment and technological change. NBER Working Paper 14832. Available at: http:// www.nber.org/papers/w14832.pdf.

Porter, M.E., van der Linde, C. 1995a. Green and Competitive. Ending the Stalemate. Harvard Business Review, September- October, 120-134.

Porter, M.E., van der Linde, C. 1995b Toward a new conception of the environmentcompetitiveness relationship. Journal of Economic Perspectives, 9(4), 97-118.

Randjelovic, J., O'Rourke, A.R., Orsato, R.J. 2003. The emergence of green venture capital. Business Strategy and the Environment, 12, 240-253.

Rennings, K. 2000. Redefining innovation - eco-innovation research and the contribution from ecological economics. Ecological Economics, 32, 319-332.

Revell, A., Stokes, D., Chen, H. 2010. Small businesses and the environment: turning over a new leaf? Business strategy and the environment 19(5), 273-288.

Savignac, F. 2008. Impact of Financial Constraints on Innovation: What Can Be Learned from a Direct Measure? Economics of Innovation and New Technology, 17(6), 553-69.

Stiglitz, J., Weiss A. 1981. Credit rationing in markets with imperfect information, American Economic Review, 71, 393-410.

Triguero, A., Moreno-Mondéjar, L., Davia, M.A. 2013. Drivers of different types of ecoinnovation in European SMEs. Ecological Economics, 92, 25-33.

Veugelers, R. 2012. Which policy instruments to induce clean innovating? Research Policy 41(10) $1770-1778$.

Walsh, P.R. 2012. Innovation nirvana or innovation wasteland? Identifying commercialization strategies for small and medium renewable energy enterprises. Technovation, 32(1), 32-42.

Zutshi, A., Sohal, A. 2004. A study of the environmental management system (EMS) adoption process within Australasian organisations -2 role of stakeholders. Technovation, 24(5), 371-386. 


\section{Working Paper del Dipartimento di Economia e Finanza}

1. L. Colombo, H. Dawid, Strategic Location Choice under Dynamic Oligopolistic Competition and Spillovers, novembre 2013.

2. M. Bordignon, M. Gamalerio, G. Turati, Decentralization, Vertical Fiscal Imbalance, and Political Selection, novembre 2013.

3. M. Guerini, Is the Friedman Rule Stabilizing? Some Unpleasant Results in a Heterogeneous Expectations Framework, novembre 2013.

4. E. Brenna, C. Di Novi, Is caring for elderly parents detrimental to women's mental health? The influence of the European North-South gradient, novembre 2013.

5. F. Sobbrio, Citizen-Editors' Endogenous Information Acquisition and News Accuracy, novembre 2013.

6. P. Bingley, L. Cappellari, Correlation of Brothers Earnings and Intergenerational Transmission, novembre 2013.

7. T. Assenza, W. A. Brock, C. H. Hommes, Animal Spirits, Heterogeneous Expectations and the Emergence of Booms and Busts, dicembre 2013.

8. D. Parisi, Is There Room for 'Fear' as a Human Passion in the Work by Adam Smith?, gennaio 2014

9. E. Brenna, F. Spandonaro, Does federalism induce patients' mobility across regions? Evidence from the Italian experience, febbraio 2014.

10. A. Monticini, F. Ravazzolo, Forecasting the intraday market price of money, febbraio 2014.

11. Tiziana Assenza, Jakob Grazzini, Cars Hommes, Domenico Massaro, PQ Strategies in Monopolistic Competition: Some Insights from the Lab, marzo 2014.

12. R. Davidson, A. Monticini, Heteroskedasticity-and-Autocorrelation-Consistent Bootstrapping, marzo 2014.

13. C. Lucifora, S. Moriconi, Policy Myopia and Labour Market Institutions, giugno 2014.

14. N. Pecora, A. Spelta, Shareholding Network in the Euro Area Banking Market, giugno 2014.

15. G. Mazzolini, The economic consequences of accidents at work, giugno 2014.

16. M. Ambrosanio, P. Balduzzi, M. Bordignon, Economic crisis and fiscal federalism in Italy, settembre 2014.

17. P. Bingley, L. Cappellari, K. Tatsiramos, Family, Community and Long-Term Earnings Inequality, ottobre 2014.

18. S. Frazzoni, M. L. Mancusi, Z. Rotondi, M. Sobrero, A. Vezzulli, Innovation and export in SMEs: the role of relationship banking, novembre 2014.

19. H. Gnutzmann, Price Discrimination in Asymmetric Industries: Implications for Competition and Welfare, novembre 2014.

20. A. Baglioni, A. Boitani, M. Bordignon, Labor mobility and fiscal policy in a currency union, novembre 2014.

21. C. Nielsen, Rational Overconfidence and Social Security, dicembre 2014.

22. M. Kurz, M. Motolese, G. Piccillo, H. Wu, Monetary Policy with Diverse Private Expectations, febbraio 2015.

23. S. Piccolo, P. Tedeschi, G. Ursino, How Limiting Deceptive Practices Harms Consumers, maggio 2015.

24. A.K.S. Chand, S. Currarini, G. Ursino, Cheap Talk with Correlated Signals, maggio 2015.

25. S. Piccolo, P. Tedeschi, G. Ursino, Deceptive Advertising with Rational Buyers, giugno 2015. 
26. S. Piccolo, E. Tarantino, G. Ursino, The Value of Transparency in Multidivisional Firms, giugno 2015.

27. G. Ursino, Supply Chain Control: a Theory of Vertical Integration, giugno 2015.

28. I. Aldasoro, D. Delli Gatti, E. Faia, Bank Networks: Contagion, Systemic Risk and Prudential Policy, luglio 2015.

29. S. Moriconi, G. Peri, Country-Specific Preferences and Employment Rates in Europe, settembre 2015.

30. R. Crinò, L. Ogliari, Financial Frictions, Product Quality, and International Trade, settembre 2015.

31. J. Grazzini, A. Spelta, An empirical analysis of the global input-output network and its evolution, ottobre 2015.

32. L. Cappellari, A. Di Paolo, Bilingual Schooling and Earnings: Evidence from a Languagein-Education Reform, novembre 2015.

33. A. Litina, S. Moriconi, S. Zanaj, The Cultural Transmission of Environmental Preferences: Evidence from International Migration, novembre 2015.

34. S. Moriconi, P. M. Picard, S. Zanaj, Commodity Taxation and Regulatory Competition, novembre 2015.

35. M. Bordignon, V. Grembi, S. Piazza, Who do you blame in local finance? An analysis of municipal financing in Italy, dicembre 2015.

36. A. Spelta, A unified view of systemic risk: detecting SIFIs and forecasting the financial cycle via EWSs, gennaio 2016.

37. N. Pecora, A. Spelta, Discovering SIFIs in interbank communities, febbraio 2016.

38. M. Botta, L. Colombo, Macroeconomic and Institutional Determinants of Capital Structure Decisions, aprile 2016.

39. A. Gamba, G. Immordino, S. Piccolo, Organized Crime and the Bright Side of Subversion of Law, maggio 2016.

40. L. Corno, N. Hildebrandt, A. Voena, Weather Shocks, Age of Marriage and the Direction of Marriage Payments, maggio 2016.

41. A. Spelta, Stock prices prediction via tensor decomposition and links forecast, maggio 2016.

42. T. Assenza, D. Delli Gatti, J. Grazzini, G. Ricchiuti, Heterogeneous Firms and International Trade: The role of productivity and financial fragility, giugno 2016.

43. S. Moriconi, Taxation, industry integration and production efficiency, giugno 2016.

44. L. Fiorito, C. Orsi, Survival Value and a Robust, Practical, Joyless Individualism: Thomas Nixon Carver, Social Justice, and Eugenics, luglio 2016.

45. E. Cottini, P. Ghinetti, Employment insecurity and employees' health in Denmark, settembre 2016.

46. G. Cecere, N. Corrocher, M. L. Mancusi, Financial constraints and public funding for ecoinnovation: Empirical evidence on European SMEs, settembre 2016. 